\title{
Review on the Use of Recyclable and Biodegradable Materials as Geosynthetics
}

\author{
Luiza Santos Giron Margalho ${ }^{1 *}$, Larissa da Silva Paes Cardoso \\ ${ }^{1}$ Senai Cimatec University Center; Salvador, Bahia, Brazil
}

\begin{abstract}
The emergence of geosynthetics changed many aspects of the project and construction of civil and environmental works. Due to the existence of a wide variety of products and the constant advancement in the development and dissemination of new technologies. These materials are applied in different engineering solutions, highlighting the possibility of using recyclable and biodegradable materials and executing geotechnical and environmental works ranging from the control of erosion to the protection of groundwater. In this context, this work presents a literature review on the use of recyclable and biodegradable materials as geosynthetic products, as well as their association with traditional geosynthetics for solutions in engineering works. The review was carried out through the platforms Google Scholar and Portal of Journals of CAPES, using keywords and Boolean connectors as descriptors. It is observed that there is a potential for the use of recyclable and biodegradable materials as geosynthetics. However, there is still a need for a careful assessment concerning the benefits, limitations, and impacts caused by the use of these wastes.

Keywords: Geosynthetics; Recyclable Materials; Biodegradable Materials; Applications.

Abbreviations: ABNT: Associação Brasileira de Normas Técnicas (Brazilian Association of Technical Standards); PET: Polyethylene Terephthalate; PETG: Polyethylene Terephthalate Glycol; PE: Polyethylene; PLA: Polylactic Acid; BPVDs: Biodegradable Prefabricated Vertical Drains.
\end{abstract}

\section{Introduction}

In recent years, the generation of solid waste in urban centers has not been accompanied by an offer of the required infrastructure to deal with all this waste. The production of these wastes is increasing in Brazil, but their proper destination, recycling, and recovery do not follow this generation's growth. In an attempt to reduce the impacts caused by these residues, the recycling of materials that are difficult to degrade has been one of the biggest concerns of our time. According to ABNT, geosynthetics are products composed of synthetic or natural polymers, in the form of a blanket, strip, or three-dimensional structure, in contact with soil or other materials, used in geotechnical and civil engineering [1]. Recyclable materials can be used as material raw in geosynthetics, filler materials for drainage, as

Received on 17 March 2021; revised 5 May 2021.

Address for correspondence: Luiza Santos Giron Margalho. Rua Praia de Aratuba, Quadra 17, Lote 16 - Lauro de Freitas, BA, 42708-750, Brazil; Phone: (55) (71) 992844498; E-mail:luizamargalho@gmail.com.

J Bioeng. Tech. Appl. Health 2021;4(2):81-84.

(C) 2021 by SENAI CIMATEC. All rights reserved. a core for geocomposites as well. They can also be used with the function of reinforcement, for the manufacture of geocells and geofibers that will act to improve the behavior of the soil [2]. This research aimed to carry out a literature review of works related to the use of recyclable and biodegradable materials as geosynthetics to better understand the possibilities and variety of products and applications in geotechnical works.

\section{Materials and Methods}

Aiming at identifying works related to the use of recyclable and biodegradable materials as geosynthetic products, as well as their association with traditional geosynthetics for solutions in engineering works, a survey of works published in the last 30 years was carried out through platforms such as Google Scholar, Portal of Journals of CAPES and the websites of renowned companies in the geosynthetics sector, such as Maccaferri and Huesker. The search descriptors adopted for the data collection were: Geosynthetics AND Biodegradable AND Environmental AND Geotechnical AND Engineering AND "Recyclable Materials". This was done to direct the results more towards the object of study. 
The logical operator AND provides results that necessarily contain these descriptors in the same document, regardless of the number of words that may exist between them. Quotation marks (“" ") were used to search for words exactly as they are written ("Recyclable Materials"), without there being any other words between them in any field. After reading the titles and abstracts, the works that had a greater focus on the research topic were identified, downloading, and reading them in full.

\section{Results and Discussion}

The number of articles found with the descriptors informed was 29. Of these articles, the 8 most relevant articles were presented (Table after excluding those that had nothing to do with the purpose of the work.

We observed that there is a potential for the use of biodegradable geosynthetics composed of natural fibers or biopolymers and recyclable materials, especially PET bottles, in the manufacture of geosynthetics and associated with products made with conventional materials. We also verified the increase of interest in Geotechnical Engineering with these materials due to their resistance, flexibility, and low environmental impact. So there is a necessity to develop a system for evaluating the performance of their use as an alternative to conventional materials.

\section{Conclusion}

We concluded that the best use of waste in engineering works is certainly important for reducing the exploitation of finite natural resources, and for preserving the environment. On the other hand, geosynthetics with their product variations and their versatility have great potential for application in geotechnical works, as well they are in constant development with new technologies, incorporation of new materials, and application methods. It is necessary to develop more careful studies to assess the performance, benefits, limitations, and impacts caused by the use of materials discarded and biodegradable materials in the manufacture of geosynthetic products, or their use associated with traditional geosynthetics in solutions in geotechnical works.

\section{References}

1. Associação Brasileira de Normas Técnicas. ABNT NBR ISO 10318-1: geossintéticos: parte 1: termos e definições. Rio de Janeiro: ABNT, 2018.

2. Teixeira AMA. A Utilização de Garrafa PET como Material Geossintético: Vantagens e Desvantagens. 2019. Available in:https://repositorio.ufpb.br/jspui/ handle/123456789/16995. Accessed in: 29 mar. 2021.

3. Cislaghi A et al. Towards more sustainable materials for geo-environmental engineering: The case of geogrids. Sustainability 2021;13(5):2585. Available in: https://www.mdpi.com/2071-1050/13/5/2585. Accessed in: 29 mar. 2021.

4. Nguyen TT, Indraratna B, Baral P. Biodegradable prefabricated vertical drains: from laboratory to field studies. Geotechnical Engineering Journal of the SEAGS \& AGSSEA 2020;51(2). Available in:https://www.researchgate.net/profile/ThanhNguyen-108/publication/341232331 Biodegradable Prefabricated Vertical Drains from Laboratory to_Field_Studies/links/5eb4e86292851cd50da137aa/ Biodegradable-Prefabricated-Vertical-Drains-fromLaboratory-to-Field-Studies.pdf. Accessed in: 29 mar. 2021.

5. Pritchard M, Alenn D. A more sustainable solution to geosynthetic products for short-term reinforcing applications. International SEEDS Conference: Engineering Design for Society 2017;3:612-627. Available in: http://eprints.leedsbeckett.ac.uk/id/ eprint/4598/. Accessed in: 29 mar. 2021.

6. Goswami P, O'Haire T. Developments in the use of green (biodegradable), recycled and biopolymer materials in technical nonwovens. Advances in Technical Nonwovens 2016:97-114. Available in: https://www.sciencedirect.com/science/article/pii/ B9780081005750000036. Accessed in: 29 mar. 2021.

7. Pranbauer $\mathrm{M}$ et al. Biodegradable geotextilesAn overview of existing and potential materials. Geotextiles and Geomembranes 2019;47(1):4859. Available in: https://www.sciencedirect.com/ science/article/pii/S0266114418300979?casa_ token=7V4Oo_KR3pcAAAAA:IqItnMga-pBvvF mvbXWTC 6 rybX0MY 1 e 9 gZ 8 GQmEFF vE- 6bFhzRWK3Q2vgOUqdZH2LeDZGv6jHvh. Accessed in: 29 mar. 2021. 
Table 1. Selected articles on the use of recyclable and biodegradable materials as geosynthetics.

\begin{tabular}{|c|c|c|c|}
\hline $\begin{array}{l}\text { Types of analyzed } \\
\text { geosynthetics }\end{array}$ & $\begin{array}{l}\text { Materials studied or } \\
\text { analyzed }\end{array}$ & Main Results & *Ref. \\
\hline Geogrids & $\begin{array}{l}\text { Biomaterials and } \\
\text { biopolymers made from } \\
\text { biodegradable Polyethylene } \\
\text { Terephthalate Glycol } \\
\text { (PETG) and polylactic acid } \\
\text { (PLA) }\end{array}$ & $\begin{array}{l}\text { Among a wide variety of biodegradable materials available on the } \\
\text { market, } 6 \text { different PLA-based materials and } 2 \text { petroleum derivatives were } \\
\text { selected as the best candidates for practical geoenvironmental engineering } \\
\text { applications. PLA-based materials are the most promising for a wide range } \\
\text { of applications in different fields. }\end{array}$ & [3] \\
\hline $\begin{array}{l}\text { Biodegradable } \\
\text { Prefabricated } \\
\text { Vertical Drains } \\
\text { (BPVDs) }\end{array}$ & Jute vegetable textile fiber & $\begin{array}{l}\text { Biodegradable drains have characteristics similar to conventional ones, } \\
\text { enabling their use in similar circumstances. BPVDs did not influence soil } \\
\text { consolidation in the period analyzed, but there was a small reduction in } \\
\text { filter tension and a slight lateral displacement due to its greater flexibility } \\
\text { compared to conventional drains. }\end{array}$ & [4] \\
\hline Geotextiles & $\begin{array}{l}\text { Natural sisal, coconut and } \\
\text { jute fibers }\end{array}$ & $\begin{array}{l}\text { Geotextiles made from natural fibers had satisfactory results in the tests } \\
\text { carried out. In relation to tensile strength, they had results similar to a } \\
\text { conventional geotextile, but they presented better results in terms of shear } \\
\text { strength and durability. }\end{array}$ & {$[5]$} \\
\hline $\begin{array}{l}\text { Nonwoven } \\
\text { Geotextiles }\end{array}$ & $\begin{array}{l}\text { Recycled materials (PET } \\
\text { and PE), biodegradable } \\
\text { polymers (polylactic acid } \\
\text { cellulose and chitosan) and } \\
\text { natural fibers. }\end{array}$ & $\begin{array}{l}\text { The use of sustainable materials in disposable non-woven applications is } \\
\text { seen as a positive factor and a way to balance human needs with a finite } \\
\text { resource reality. Verifying that such materials have characteristics similar to } \\
\text { commonly used synthetic nonwovens. }\end{array}$ & {$[6]$} \\
\hline $\begin{array}{l}\text { Geosynthetics } \\
\text { (geocells and } \\
\text { geofibers) }\end{array}$ & PET bottles & $\begin{array}{l}\text { The combinations of geosynthetics with PET bottles reduce construction } \\
\text { costs and reduce the volume of waste that would end up in landfills. PET } \\
\text { bottles can be used as a raw material for geotextiles, as a filling material } \\
\text { for drainage in buildings and to form drainage mats under a geotextile } \\
\text { filter. They can also be used with the function of reinforcement, for the } \\
\text { manufacture of geocells and geofibers that will act to improve the behavior } \\
\text { of the soil. }\end{array}$ & [2] \\
\hline Geotextiles & $\begin{array}{l}\text { Natural fibers and } \\
\text { biopolymers }\end{array}$ & $\begin{array}{l}\text { Considering the containment of the accumulation of additives and } \\
\text { microplastics in the environment, as well as the need to recover the } \\
\text { materials after the growth of natural vegetation, biodegradable geotextiles } \\
\text { made from jute and coconut mats are inexpensive and remain intact for } \\
\text { about } 1-3 \text { years. They show improvement in the sowing process and growth } \\
\text { of planted vegetation and represent a suitable alternative to melt-spun } \\
\text { thermoplastic fibers for slopes, which are not very steep }\left(<45^{\circ}\right) \text {. However, } \\
\text { natural fibers absorb large amounts of water, which can lead to significant } \\
\text { weight gain and premature degradation of the geotextile making the } \\
\text { application of natural fibers in specific environments, such as riverbanks or } \\
\text { steep slopes, unfeasible. }\end{array}$ & {$[7]$} \\
\hline Geotextiles & $\begin{array}{l}\text { Natural fibers and } \\
\text { biopolymers }\end{array}$ & $\begin{array}{l}\text { Biotextiles have great potential to become commonly used materials due } \\
\text { to the growing interest in the market, their competitive properties and the } \\
\text { need to use them not only in innovative solutions, but also in widely known } \\
\text { environmental works. There are several examples of plant and animal } \\
\text { source fibers that provide a competitive alternative option to synthetic } \\
\text { products commonly used in short term solutions, they include jute, coconut } \\
\text { fiber or wool. These fibers are characterized by having good mechanical } \\
\text { properties and low production costs. Furthermore, they break down into } \\
\text { elements that pose no risk to the environment and can even be used as a } \\
\text { fertilizer for plants. }\end{array}$ & [8] \\
\hline Geocell & PET bottles & $\begin{array}{l}\text { PET bottles have adequate mechanical strength, which is an indication of } \\
\text { their viability for use in the construction industry. A PET bottle geocell has } \\
\text { properties that make it able to respond very well to the necessary stresses, as } \\
\text { the alternative structure is very similar: hollow, so the opening mesh allows } \\
\text { for greater interaction and anchoring in the inserted soil. }\end{array}$ & [9] \\
\hline
\end{tabular}


8. Daria M, Krzysztof L, Jakub M. Characteristics of biodegradable textiles used in environmental engineering: A comprehensive review. Journal of Cleaner Production 2020:122-129. Available in: https://www.sciencedirect.com/science/article/pii/ S0959652620321764. Accessed in: 29 mar. 2021.
9. Dos Santos CS et al. Uso de Garrafa de Poli Tereftalato de Etileno - PET para a Produção de Geocélula. $16^{\circ}$ Congresso Brasileiro de Geologia de Engenharia e Ambiental. São Paulo, 2018. Available in: http://www.schenautomacao.com.br/cbge/envio/ files/trabalho_195.pdf. Accessed in: 29 mar. 2021. 